\title{
ALEKSANDRA KRAWCZUK
}

(Katowice)

\section{PRZYCZYNOWOŚĆ A CELOWOŚĆ}

Kiedy problem przyczynowości próbuje się rozważyć w kontekście celowości, wówczas wymaga to rozważenia tego zagadnienia w kilku płaszczyznach. Oczywiście najważniejsze jednak są: płaszczyzna ontologiczna i epistemologiczna, chociaż problem wymaga także rozważenia w płaszczyźnie etycznej. Jednakże z drugiej strony złożoność problematyki nakłada stosowne ograniczenia, jakie trzeba poczynić, aby można było w ogóle dokonać jakichkolwiek analiz. Przede wszystkim bowiem trzeba sobie jasno i wyraźnie uświadomić, że wraz z pytaniem o cel, czytelnik wkracza w świat filozofii całej, a nie tylko próbuje rozważyć określony wycinek jej dziejów. Wystarczy wskazać na pierwszą księgę Metafizyki Arystotelesa, aby uzmysłowić sobie znaczenie pojęcia przyczyny dla naszego rozumienia rzeczywistości. Arystoteles wiąże znajomość przyczyn z mądrością, podkreślając, że ludzie mądrzy „mają poznanie przyczyn" ${ }^{1}$, a nieco dalej stwierdza, że „tak zwana mądrość polega na poznaniu pierwszych przyczyn i zasad" ${ }^{2}$. Jeszcze dalej Stagiryta podkreśla, że „w ogóle mądrość polega na dociekaniu przyczyny zjawisk" ${ }^{3}$. Mówiąc o przyczynach Arystoteles twierdzi, że istnieją cztery rodzaje przyczyn, a mianowicie przyczyna materialna, formalna, sprawcza i celowa. Dla filozofa ze Stagiry ta ostatnia jest bardzo ważna, gdyż określa sens ludzkiego działania. „Słusznie - zauważa Arystoteles, mając na względzie przyczynę celową też nazywa się filozofię nauką o prawdzie. Albowiem celem nauki teoretycznej jest

\footnotetext{
1 Arystoteles, Metafizyka, tłum. M. A. Krąpiec, A. Maryniarczyk, Lublin 1996, 981 a, 30.

2 Tamże, 981 b, 28-29.

3 Tamże, 992 b, 25-26.
} 
prawda, tak jak celem nauki praktycznej - działanie. (...) Nie znamy zaś prawdy, jeśli nie znamy przyczyny" 4 .

Te kilka uwag zaczerpniętych z najważniejszego tekstu Arystotelesa wystarczy, aby pokazać ważność problematyki przyczynowości na gruncie filozofii, zwłaszcza wtedy, kiedy chce się ten problem rozważyć w kontekście celowości. Jest to o tyle ważne, że przecież - jak zauważa Arystoteles - celem filozofii teoretycznej jest prawda, zaś praktycznej - działanie. Tym samym, z jednej strony postrzeganie celowości uzasadnia ludzkie działanie i w tym sensie jest ona ważna dla ludzkiej orientacji w świecie, z drugiej storny jednak pojawia się problem, gdyż nie zawsze celowość wiązana jest z przyczynowością. W Powszechnej Encyklopedii Filozofii czytamy, że przyczyna celowa „ontycznie uzasadnia czyny, zmiany i ruch, będąc motywem, dla którego coś raczej działa niż nie działa" ${ }^{5}$. Problem w tym, że cel stanowi motyw ludzkich działań, które ostatecznie wszystkie do niego zmierzają. Każde działanie ma swój cel, który zostaje wyznaczony bądź przez działającego, bądź też działającemu przez kogoś innego.

Skrótowe omówienie problematyki celu zostanie przedstawione w odniesieniu do dwóch płaszczyzn, a mianowicie płaszczyzny poznawczej i płaszczyzny etycznej. Nie uwzględnia całościowego spojrzenia na problem celowości w nauce i filozofii, gdyż opiera się na założeniu, ze problem celu stanowi jeden z najistotniejszych problemów całej nauki (i filozofii). Nauka wyznacza sobie cele, względnie cele, a tak samo cel wyznacza sobie filozofia. Problem wszakże w tym, że cele te wyznaczają postrzeganie nauki i filozofii, a tym samym z góry rozstrzygają wstępnie pewne kwestie metodologiczne. To jednak przekracza ramy tej prezentacji.

\section{I.}

Problem, z jakim ma do czynienia ktoś, kto próbuje zastanowić się nad relacją między przyczyną a celem, jest przede wszystkim problemem relacji między środkami a celami. Najogólniej można powiedzieć, że środki powinny być takie, aby można było osiągnąć cel, ba, by cel ten osiągnąć w możliwie najprostszy sposób. Pisze o tym Konstantin Spiridonowicz Bakradze (1898-1970) w swej książce poświęconej filozofii współczesnej, w miejscu, w którym analizuje poglądy filozoficzne przedstawiciela empiriokrytycyzmu, Richarda Avenariusa (1843-1896) ${ }^{6}$.

\footnotetext{
4 Tamże, 993 b, 20-25.

5 M. A. Krąpiec, Przyczyny bytu, w: Powszechna Encyklopedia Filozofii, t. 8: Pap-Sc, Lublin 2007 , s. 528.

6 Zob. K. Bakradze, Z dziejów filozofii wspótczesnej, tłum. H. Zelnikowa, Warszawa 1964, s. $48 \mathrm{nn}$.
} 
Filozofia Avenariusa o tyle jest symptomatyczna dla rozumienia relacji między przyczyną (środkiem) a celem, że twórca empiriokrytycyzmu stworzył zasadę najmniejszego wysiłku myślenia, którą Bakradze streszcza w sposób następujący: „Środki powinny być takie, żeby można było osiągnacć cel, a najlepszy pośród wszystkich środków będzie ten, który pozwoli ów cel osiągnąć najmniejszym nakładem sił. (...) Działanie wedle zasady najmniejszego wysiłku - to działanie celowe" 7. Temu właśnie zagadnieniu poświęcona była rozprawa habilitacyjna Avenariusa, zatytułowana Philosophie als Denken der Welt gemäss dem Princip des kleinsten Kraftmasses (Filozofia jako myślenie o świecie wedtug zasady najmniejszego wysiłku. Prolegomena do krytyki czystego doświadczenia) ${ }^{8}$. Jest to symptomatyczne również z tego powodu, że niejako wpisuje się w poszukiwania dotyczące rozumienia nauki. „Avenarius - pisze o tym Leszek Kołakowski - był przekonany, że każda nauka w sposób naturalny zmierza do tego, by zaspokoić żywe w umyśle ludzkim pragnienie jedności; każda tedy chce ukonstytuować syntetyczny ogląd własnego obszaru badań w jakimś pojęciu ostatecznym i najwyższym" 9 .

Właśnie w owym „pojęciu ostatecznym i najwyższym” ujawnia się celowy charakter wszelkiej aktywności teoretycznej. Tym bardziej jest to ważne, że kiedy pojawia się problem empiriokrytycyzmu, to ujawnia się w kontekście genezy nauki. Krytyka doświadczenia w ujęciu Avenariusa polegać ma oczyszczeniu go z elementów, które nie mają wiele wspólnego z doświadczeniem. „Zawarta w koncepcji Avenariusa - pisze w tym kontekście Andrzej J. Noras - krytyka doświadczenia wyrasta z określonego rozumienia filozofii, za którym kryje się osobliwe rozumienie doświadczenia" ${ }^{10}$. Rzeczywiście filozofia Richarda Avenariusa może się okazać symptomatyczna dla rozumienia celu w poznaniu teoretycznym, gdyż ukazuje założeniowy, stanowiskowy charaketr filozofii Avenariusa, choć także założeniowy charakter wielu stanowisk. Oczywiście także założeniowy charakter ludzkiego wyznaczania celów w działaniu.

Wcześniej jednak pojęcie celowości analizował Immanuel Kant, który poświęcił mu obszerne fragmenty Krytyki władzy sadzenia. „Celowość przyrody pisał we wstępie Kant - jest więc szczególnym pojęciem a priori, które ma swe źródło jedynie w refleksyjnej władzy sądzenia. Wytworom przyrody bowiem nie można przypisywać czegoś takiego, jak to, że przyroda w nich odnosi się do celów;

\footnotetext{
7 Tamże, s. 49.

8 R. Avenarius, Philosophie als Denken der Welt gemäss dem Princip des kleinsten Kraftmasses. Prolegomena zu einer Kritik der reinen Erfahrung, Leipzig 1876.

9 L. Kołakowski, Filozofia pozytywistyczna. Od Hume'a do Koła Wiedeńskiego, Warszawa 2003, s. 110-111.

10 A. J. Noras, Kant $i$ Hegel $w$ sporach filozoficznych osiemnastego $i$ dziewiętnastego wieku, Katowice 2007, s. 219-220.
} 
pojęciem tym zaś wolno posługiwać się tylko do tego, by zastanawiać się nad przyrodą (sie zu reflektieren) z punktu widzenia danego podług praw empirycznych związku zachodzących w niej zjawisk. Pojęcie to jest całkowicie różne od praktycznej celowości (sztuki ludzkiej lub nawet obyczajów), chociaż pomyślane jest na podstawie pewnej analogii do niej" ${ }^{11}$. Warto wskazać na znaczenie tej książki Kanta, tzw. trzeciej krytyki, gdyż opiera się ona na rozróżnieniu między krytyką a systemem, a jednocześnie zamiarem autora było zbudowanie pomostu między pierwszą a drugą krytyką, między Krytyka czystego rozumu a Krytyka praktycznego rozumu. Dlatego jeden z podrozdziałów Wstępu do Krytyki władzy sadzenia Kant zatytułował O krytyce władzy sądzenia jako o środku spajajacym dwie części filozofii w jedna całość12.

O celowości przyrody mówi także Kant w Pierwszym wprowadzeniu do „Krytyki władzy sądzenia”. „Stąd wypływa - pisze Kant - pojęcie celowości przyrody, i to jako swoiste pojęcie refleksyjnej władzy sądzenia, a nie rozumu, albowiem cel wcale nie zostaje umieszczony w przedmiocie, lecz tylko w podmiocie, a mianowicie w samej jego władzy dokonywania refleksji" ${ }^{13}$. Kant zatem, co niezwykle interesujące wiąże tu pojęcie celu z podmiotem, a celowość tę nazywa celowością logiczną. Jest to o tyle istotne, że gdyby dokonać analizy Krytyki władzy sadzenia przez pryzmat występującego w niej pojęcia celu, wówczas okaże się, że Kant posługuje się wieloma jego rozumieniami. Otóż, zdaniem Kanta, cel może być rozumiany jako „pojęcie pewnego przedmiotu, o ile zawiera ono zarazem rację rzeczywistości tego przedmiotu” ${ }^{14}$, następnie jako „przedmiot pojęcia, o ile uważamy je za przyczynę tego przedmiotu (za realną podstawę jego możliwości)” 15 albo „wytwór (...) przyczyny, której racją determinującą jest jedynie przedstawienie jej skutku" 16 . Cel może być celem wewnętrznym i zewnętrznym, subiektywnym i obiektywnym, względnym (relatywnym) i absolutnym. To wszystko uświadamia czytelnikowi, że pojęcie celu nie jest pojęciem prostym, ale z konieczności musi rodzić wiele trudności. Tym bardziej, że rozumienie celowości w ścisłym związku z przyczynowością przyrody jest radykalną redukcją jej obszaru obowiązywania. Wprawdzie w Pierwszym wprowadzeniu do „Krytyki władzy sądzenia” autor mówi przede wszystkim o pojęciu celowości w kontekście przyrody, ale przecież w dalszej części książki mówi o jej różnorodnych rozumieniach. „Przez celowość absolutna - pisze Kant

11 I. Kant, Krytyka władzy sadzenia, tłum. J. Gałecki, Warszawa 1986, s. 26.

12 Zob. tamże, s. 19.

13 I. Kant, Pierwsze wprowadzenie do „Krytyki władzy sadzenia”, tłum. J. Nowotniak, „Idea. Studia nad strukturą i rozwojem pojęć filozoficznych" VI, Białystok 1993, s. 27.

14 I. Kant, Krytyka wladzy sadzenia, wyd. cyt., s. 26.

15 Tamże, s. 89.

16 Tamże, s. 388. 
w Pierwszym wprowadzeniu... - form przyrody rozumiem ten kształt zewnętrzny, jak też ich wewnętrzną budowę, które są tego typu, że u podstaw ich możliwości musi się zakładać w naszej władzy sądzenia ich ideę. Celowość jest bowiem prawidłowością tego, co przypadkowe jako takiego" 17. Ostatnie zdanie jest nie tylko symptomatyczne dla Kanta, ale też ma fundamentalne znaczenie dla rozumienia celowości w ogóle. Kant mówi o tym, że celowość jest „prawidłowością tego, co przypadkowe jako takiego", co można rozumieć dwojako. Po pierwsze, celowość jest prządkiem istniejącym w przyrodzie oraz, po drugie, celowość jest wprowadzaniem porządku w przyrodzie. Pierwsze znaczenie uwyraźnia się w rozumie teoretycznym, drugie - w praktycznym.

Kiedy z kolei odnieść się do niemal współczesnego tekstu, wówczas okazuje się, że problem postrzegany jest nieco inaczej. Roman Ingarden postrzega przyczynowość w kontekście procesu poznawania. Mówi on o psychofizjologicznej teorii poznania, która poznanie rozumie „(...) jako jeden ze stosunków przyczynowych zachodzących między człowiekiem a jego otoczeniem, w szczególności przedmiotem poznawanym" 18. Takie ujęcie pokazuje inną stronę medalu, a mianowicie konieczność rozważenia nie tyle celu, ile pojęcia przyczyny ze względu na cel. To jednak wiąże się ściśle z charakterem badań przeprowadzonych przez Ingardena, który w trzecim tomie Sporu o istnienie świata analizuje przyczynowość w świetle najnowszych osiągnięć fizyki świata atomowego. Ma to kolosalne znaczenie dla rozumienia przyczynowości, ale nie do końca jest oczywiste, czy zmienia rozumienie celowości, zwłaszcza w świetle celowej aktywności człowieka.

Jak więc widać na tych kilku przytoczonych przykładach, motyw ustanowienia celu jest motywem powracajaccym bez przerwy w badaniach naukowych. Można w tym miejscu rozważania zamknąć, wychodząc z założenia wskazującego na konieczność przeprowadzenia gruntownych badań z zakresu metodologii. Dość powiedzieć, że najlepszym dowodem aktualności problematyki celowości jest fakt, że stanowi ona bardzo wyraźny motyw filozofowania dwudziestowiecznego. Nie tylko, jak zostało to zasygnalizowane, myślenie porusza się w obszarze problemów, ale również w sferze metodologii. Innymi słowy, kiedy uświadomiono sobie wage problematyki metody, wówczas z całą mocą pojawił się problem nauki. Dlatego też pojawia się tu jeszcze jeden problem, który z perspektywy nauki jest niezwykle istotny, a mianowicie problem bezzałożeniowości. Skoro bowiem nauka musi pozostać bezzałożeniowa, to nie można mówić o ustanowieniu celu w sensie kresu, a tylko ustanowieniu celu w sensie postępowania metodycznego. Rzecz jednak w tym, czy postulowaną bezzałożeniowość da się zrealizować? Tym bardziej, że z jeszcze większą mocą występuje tu problematyka celu.

17 I. Kant, Pierwsze wprowadzenie do „Krytyki wladzy sadzenia”, wyd. cyt., s. 28.

18 R. Ingarden, U podstaw teorii poznania. Część pierwsza, Warszawa 1971, s. 158. 
Problem jest jednak bardzo złożony, na co w odniesieniu do Edmunda Husserla wskazuje ks. Jan Krokos, akcentujący fakt, że prezentacja fenomenologii wymaga odwołania się do dwóch idei, jakie fenomenologia Husserla chciała urzeczywistnić, a mianowicie idei „filozofii pierwszej i nauki ścisłej” ${ }^{19}$. W odniesieniu do pierwszej idei ważne są wykłady o filozofii pierwszej, które Husserl wygłosił we Fryburgu Bryzgowijskim w semestrze letnim 1923/24. Ks. Krokos przytacza fragment z tych wykładów, gdzie Husserl pisał: „Nazwa »filozofia pierwsza « wskazywałaby na naukową dyscyplinę początku (eine wissenschaftliche Disziplin des Anfangs); z niej wynikałoby, że główna teleologiczna idea (die oberste Zweckidee) filozofii domagałaby się swoistej w sobie zamkniętej dyscypliny o początku lub o zamkniętym obszarze początków, z własną problematyką początków, po duchowym przygotowaniu, po ścisłym sformułowaniu i następnie naukowym rozwiązaniu. Z wewnętrznej nierozdzielnej konieczności byłaby to dyscyplina idąca przed (vorangehen) wszystkimi innymi dyscyplinami filozoficznymi, które metodycznie i teoretycznie musiałaby ufundować. Brama wyjściowa, początek samej filozofii pierwszej byłby następnie początkiem wszystkich filozofii w ogólności" 20. Fragment, który przytacza ks. Krokos, pokazuje bardzo dobitnie, że problematyka celowościowa tkwi u podstaw analiz dotyczących rozumienia filozofii, a więc również wiedzy, gdyż „idea filozofii pierwszej jest dla Husserla jedynie pewną ideą teleologiczną (Zweckidee)" 21. Tym samym ukazuje się bardzo wyraźnie celowościowy charakter nauki, który okazuje się być szczególnie ważny ze względu na jej jedność.

\section{II.}

Na płaszczyźnie etycznej wskazać warto na dokonania kilku znaczących postaci, choć oczywiście z zastrzeżeniem, że analiza ma charakter wybiórczy, choć jak się okaże - nieprzypadkowy. Tomasz z Akwinu wyróżnia cztery etapy świadomego aktu wyboru, a mianowicie intencję (intentio), rozwage (consilium), przyzwolenie bądź zgodę (consensus) oraz wolny wybor (electio). Analiza aktu wyboru rozpoczyna się od intencji sprowadzającej się do wyboru celu, do którego

19 Ks. J. Krokos, Koncepcja fenomenologii w ujęciu Husserla, Pfändera, Schelera i niektórych ich uczniów, Warszawa 1992, s. 20.

20 E. Husserl, Erste Philosophie (1923/23), hrsg. von R. Boehm, t. 1, Kritische Ideengeschichte, Den Haag 1956, s. 5. Cyt. za: Ks. J. Krokos, Koncepcja fenomenologii w ujęciu Husserla..., wyd. cyt., s. 20-21.

21 Ks. J. Krokos, Koncepcja fenomenologii w ujęciu Husserla..., wyd. cyt., s. 21. 
ma zmierzać czyn i tak rozumiana intencja jest aktem o charakterze intelektualno-wolitywnym. Występują tu dwa elementy. Po pierwsze, intelektualne, poznawcze uchwycenie celu oraz, po drugie, dążenie do celu, bo poznając cel, chcę już do niego zmierzać. Akt intencji jest więc aktem złożonym, w którym występują moment intelektualny, tzn. poznanie oraz moment wolitywny, czyli pożądanie.

Taka charakterystyka intencji przez Tomasza z Akwinu - i bezpośrednie powiązanie jej z celem oraz poznaniem - ujawnia się również u filozofa, którego prawdopodobnie trudno podejrzewać o związki z Tomaszem, a mianowicie u Immanuela Kanta. Tym bardziej, że - jak słusznie zauważa Karol Bal - Kant zrywa z rozumieniem dobra charakterystycznym dla czasów go poprzedzających: „W większości teorii etycznych przed Kantem wyprowadzano z pojęcia dobra (człowiek, społeczeństwo, przyroda lub Bóg jako wartości najwyższe) konkretne wskazówki dla postępowania moralnego" 22. Sam Kant bowiem w Krytyce praktycznego rozumu pisze, że „nie pojęcie dobra jako przedmiotu określa i umożliwia prawo moralne, lecz na odwrót, dopiero prawo moralne określa i umożliwia pojęcie dobra, o ile ono na tę nazwę zasługuje" 23. Takie ujęcie, na co zresztą zwraca uwagę Bal, nie jest wolne od błędów, chociaż interesujące z perspektywy celu jest tu następujące stwierdzenie: „Kiedy filozof mówi, że dobro lub cel mogą być uznane za wartość moralną wowczs jedynie, gdy nie przeczą prawu moralnemu - to wypada się z nim zgodzić. Lecz gdy stwierdza następnie, że cel w ogóle (cel rozumny, pozanaturalny, etc.) jest skutkiem, nie zaś podstawą moralności, to przez to odbiera morlności podstawę, na której się ona wspiera" ${ }^{24}$. Widać zatem, że kwestia celu bardzo mocno się komplikuje i tym samym komplikuje rozumienie rzeczywistości etycznej.

Interesujące jest powiązanie przez Kanta osoby z celem samym w sobie. „Powodem - pisze na ten temat Paweł Łuków - łączenia bezwarunkowości wartości dobrej woli z bezwarunkowością wartości osób wydaje się to, że wprowadzając formułę celu samego w sobie, Kant twierdzi, iż istoty rozumne jako cele postępowania posiadają wartość bezwzględną, zaś wszystkie inne cele mają wartość tylko warunkową" ${ }^{25}$. Zarazem jednak trzeba się odwołać do samego Kanta, który - czego w żaden sposób nie można postrzegać jako czegoś osobliwego - cel wiąże z rozumnością. Tym samym możliwość ustanowienia celu staje się wyznacznikiem człowieczeństwa. „Wolę - pisze Kant w Uzasadnieniu metafizyki moralności

22 K. Bal, Transcendentalizm a historyzm. Rozdroża etyki Kanta, w: Filozofia transcendentalna a dialektyka, red. M. J. Siemek, Warszawa 1994, s. 57.

23 I. Kant, Krytyka praktycznego rozumu, tłum. J. Gałecki, Warszawa 1984, s. 106.

24 K. Bal, Transcendentalizm a historyzm, wyd. cyt., s. 57-58.

25 P. Łuków, Wolność i autorytet rozumu. Racjonalność w filozofii morlanej Kanta, Warszawa 1997, s. 151. 
- pojmujemy jako zdolność samodzielnego nakłaniania się do czynu zgodnie z przedstawieniem pewnych praw. Taką zdolność możemy zaś spotkać tylko $\mathrm{w}$ istotach rozumnych. Tym, co służy woli za obiektywną podstawę do samookreślenia się, jest cel, ten zaś - jeżeli dany jest przez sam tylko rozum - musi obowiązywać w równej mierze wszystkie istoty świadome" 26 .

Tutaj jednak dalej komplikuje się rozumienie celu przez Kanta, gdyż wprawdzie warunkiem pojawienia się celu jest rozumność, to jednak ukazuje się tu kolejna komplikacja, a mianowicie pojawia się relacja między celem a środkiem: „Co zaś zawiera tylko podstawę możliwośći czynu, którego skutek jest celem, zwie się środkiem" ${ }^{27}$. Kant wyróżnia tu cele subiektywne i obiektywne. W pierwszym wypadku chodzi o takie cele, które opierają się na pobudkach, w drugim - na motywach. Ponadto mówi Kant o celach względnych, jako wyznaczonych skutkach swoich własnych czynów i mając tę względność na uwadze pisze: „Przypuśćmy jednak, że istniałoby coś, czego istnienie samo w sobie posiada bezwzględną wartość, a co jako cel sam w sobie mogłoby tworzyć podstawę pewnych praw; $\mathrm{w}$ takim razie $\mathrm{w}$ tym i tylko $\mathrm{w}$ tym leżałaby podstawa (Grund) możliwego kategorycznego imperatywu, tj. praktycznego prawa" 28 . Z tego więc wynika dla Kanta, że człowiek może istnieć jako cel sam w sobie, a nie tylko środek. $\mathrm{Z}$ tego też wynika dla autora Uzasadnienia metafizyki moralności praktyczny imperatym, który w jego przekonaniu winien brzmieć następująco: „Postępuj tak, byś człowieczeństwa tak w twej osobie, jak też w osobie każdego innego używał zawsze zarazem jako celu, nigdy tylkojako środka" 29 .

Roman Ingarden, o czym była powyżej mowa, kwestię determinizmu rozważa w trzecim tomie Sporu o istnienie świata, który poświęcony jest zagadnieniu przyczynowości ${ }^{30}$. Ważność zaproponowanych przez Ingardena rozstrzygnięć Tadeusz Czarnik charakteryzuje tak: „Ingarden odrzuca możliwość radykanego determinizmu, lecz określenie tego determinizmu jest tak odmienne od przyjętego powszechnie, że wnioski jakie wyprowadza musiałyby być jednak zweryfikowane pod kątem dotychczasowych pojęć. Także sama argumentacja nawet na gruncie pojęć Ingardena nie zawsze pozwala na odrzucenie tego rodzaju determinizmu" ${ }^{31}$.

26 I. Kant, Uzasadnienie metafizyki moralności, tłum. M. Wartenberg, przejrzał R. Ingarden, Warszawa 1984, s. 59-60.

27 Tamże, s. 60.

28 Tamże.

29 Tamże, s. 62.

30 R. Ingarden, Spór o istnienie świata, t. 3: O strukturze przyczynowej realnego świata, tłum.

D. Gierulanka, Warszawa 1981.

31 T. Czarnik, Czy wolność jest możliwa? Zagadnienie wolności i przyczynowości w filozofii Romana Ingardena, Kraków 1999, s. 176. 
Problem determinizmu nie może więc być rozwiązany jednoznacznie, gdyż albo pojawiają się trudności terminologiczne, albo też - co dzieje się częściej - problemy terminologiczne powodują, że dyskusja toczy się przy braku terminologicznej jednomyślności. Jednocześnie warto zaakcentować fakt, że pojawiające się rezultaty badawcze mogą stanowić podstawę do dyskusji nad rozumieniem celowości. Dlatego też warto odnieść się do jeszcze jednego filozofa współczesnego, który problem ten podejmuje w kontekście relacji między przyczyną a celem, a mianowicie do Nicolaia Hartmanna. W swej etyce podejmuje on bowiem w sposób systematyczny kwestię tej relacji.

Problem celowości podejmuje Hartmann na dwóch płaszczyznach, a mianowicie ontologicznej i etycznej, przy czym tę pierwszą z góry wyklucza wychodząc z założenia, że jedynym typem celowości jest możliwość aktywności celowej wyrażającej się w ustanawianiu celów. Taka teza uzasadniona zostaje dwojako. Po pierwsze, przez brak możliwości wykazania istnienia innej celowości w świecie (tutaj - o czym za chwilę - ujawnia się złożony charakter celowości) oraz, po drugie, powiązanie celowości z możliwością wyznaczenia celów przez działającego człowieka. Tomasz z Akwinu wskazywał na następujące elementy aktu wyboru: intencja (intentio), rozwaga (consilium), przyzwolenie (consensus) i wolny wybór (electio). Nicolai Hartmann również akcentuje złożony charakter związku celowego. „O ile - pisze na ten temat Andrzej J. Noras - związek przyczynowy stanowi wielość względnie izolowanych systemów, o tyle związek celowy łączy trzy ściśle ze sobą powiązane akty. Są to: a) ustanowienie celu w świadomości, połączone z antycypacją przyszłości, a więc określające z góry porządek chronologiczny; b) selekcja środków w świadomości ze względu na ustanowiony cel; Hartmann mówi o wstecznej determinacji (rückläufige Determination), niezgodnej z porządkiem czasowym; c) realizacja celu za pomocą szeregu ustanowionych środków" 32. Teza Hartmanna o tyle jest istotna, że udaje mu się pokazać ścisłą zależność między związkiem przyczynowym a celowym, a mianowicie wówczas, kiedy okazuje się, że realizacja celu ma charakter przyczynowy. W swojej Ethik (1926) Hartmann bowiem zauważył: „W rzeczywistości związek celowy jest już zawsze wpleciony w istniejacy splot (Geflecht) determinacji przyczynowej" ${ }^{33}$. Tym samym ukazuje się ścisły związek koncepcji Hartmanna z przedstawioną przez Immanuela Kanta, gdyż w jednym i drugim wypadku związek celowy oznacza nabudowanie się na związku przyczynowym. Innymi słowy, zarówno Hartmann jak i Kant są przekonani, że związek przyczynowy stanowi warunek sine qua non związku celowego.

32 A. J. Noras, Nicolaia Hartmanna koncepcja wolności woli, Katowice 1998, s. 79.

33 N. Hartmann, Ethik, Berlin - Leipzig 1926, s. 187. Cyt. za A. J. Noras, Nicolaia Hartmanna koncepcja wolności woli, wyd. cyt., s. 79. 
Jest to o tyle istotne, że zdaje się tu ujawniać realizm autorów w ocenie ontologicznej struktury świata realnego.

Jak pokazuje ta krótka analiza, problem rozumienia celowości jest niezwykle złożony, gdyż musi uwzględnić kilka czynników, spośród których na plan pierwszy wysuwa się problem ontologicznego rozumienia struktury świata realnego. Na plan drugi wysuwa się problem etyczny, ale tylko z powodu - wskazanej przez Kanta i Hartmanna - zależności wystąpienia związku celowego od istnienia związku przyczynowego. I wreszcie na trzecim miejscu pojawia się problem rozumienia rzeczywistości, ujawniający się np. w rozumieniu doświadczenia, któremu nadaje się charakter celowy. 